\title{
40 years of anorexia nervosa: why we should never give up
}

Stephanie Hill, Anthea Fursland

From 2014 ANZAED Conference: Driven Bodies Driven Brains

Fremantle, Australia. 22-23 August 2014

A case will be presented of a 54 year old woman who struggled with anorexia since age 16 without treatment, until a starvation fuelled incident of shoplifting triggered her to seek help for her eating disorder. Her anxious demeanour over her many phone calls and her intial BMI of 15 did not look hopeful. However, she has done remarkably well with 34 sessions of Enhanced Cognitive Behaviour Therapy over 15 months, and has stabilised at a BMI of 20.2, with an EDE-Q score within community norms. Creating a life without anorexia has been an ongoing challenge, but she is grateful that she is now physically and emotionally well enough to embark on this journey. This case illustrates why we should never give up on severe and enduring cases, and why we should always consider the possibility of full recovery, over and above quality of life improvements.

This abstract was presented in the Treatment in Community and Inpatient Settings stream of the 2014 ANZAED Conference.

Published: 24 November 2014

doi:10.1186/2050-2974-2-S1-010

Cite this article as: Hill and Fursland: 40 years of anorexia nervosa: why we should never give up. Journal of Eating Disorders 2014 2(Suppl 1):010.

* Correspondence: stephanieclare.hill@health.wa.gov.au

Centre for Clinical Interventions, Perth, Australia

Submit your next manuscript to BioMed Central and take full advantage of:

- Convenient online submission

- Thorough peer review

- No space constraints or color figure charges

- Immediate publication on acceptance

- Inclusion in PubMed, CAS, Scopus and Google Scholar

- Research which is freely available for redistribution 